\title{
Covid-19 pandemic and the motivations for demanding health service in indigenous villages
}

\author{
Pandemia covid-19 e motivações para procura pelo Sistema Único de Saúde em aldeias indígenas \\ Covid-19 pandemia y motivaciones para buscar el servicio de salud en pueblos indígenas
}

\section{Aridiane Alves Ribeiro' ORCID: 0000-0003-2702-9332 \\ Lídia Aparecida Rossi" \\ ORCID: 0000-0002-4141-861X}

'Universidade Federal de Jataí. Jataí, Goiás, Brazil. "Universidade de São Paulo. Ribeirão Preto, São Paulo, Brazil.

How to cite this article:

Ribeiro AA, Rossi LA. Covid-19 pandemic and the motivations for demanding health service in indigenous villages. Rev Bras Enferm. 2020;73(Suppl 2):e20200312 doi: http://dx.doi.org/10.1590/0034-7167-2020-0312

Corresponding author:

Aridiane Alves Ribeiro

E-mail: aridiane@ufg.br

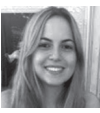

EDITOR IN CHIEF: Dulce Barbosa ASSOCIATE EDITOR: Hugo Fernandes

Submission: 04-18-2020

Approval: 08-09-2020

\section{ABSTRACT}

Objective: To discuss the fundamental aspects in the establishment of preventive measures to tackle covid-19 among indigenous people in view of the motivations for seeking health care in villages of the Terra Indígena Buriti, Mato Grosso do Sul, Brazil. Methods: Theoretical-reflective study based on assumptions of the National Health System and previous ethnographic research that enabled the identification of the motivations to seek health care in Buriti villages. Results: Indigenous people seek health centers for health care programs assistance, treatment of cases they cannot resolve and to chat. Such motivations were the basis for discussing the indigenization process in the confrontation of the new coronavirus pandemic in indigenous lands. Final considerations: The motivations for seeking health care show the physical and social vulnerability of the Terena ethnicity. The effectiveness of the social isolation measure in the villages depends on the dialogue with indigenous leaders, professional engagement and intersectoral actions.

Descriptors: Health Services, Indigenous; Delivery of Health Care; Anthropology, Cultural; Vulnerable Populations; Pandemics.

\section{RESUMO}

Objetivo: Discutir aspectos fundamentais no estabelecimento de medidas preventivas no enfrentamento da covid-19 entre indígenas frente às motivações para busca dos serviços de saúde nas aldeias da Terra Indígena Buriti, Mato Grosso do Sul, Brasil. Métodos: Estudo teórico-reflexivo fundamentado nos pressupostos do Sistema Único de Saúde e em pesquisa etnográfica prévia, que possibilitou identificar as motivações para a procura do serviço de saúde nas aldeias Buriti. Resultados: Os indígenas buscam unidades de saúde para atendimento de programas de atenção à saúde, tratamento para casos que não conseguem resolver e para conversar. Tais motivações fundamentaram a discussão do processo de indigenização do enfrentamento da pandemia do novo coronavírus em terras indígenas. Considerações finais: As motivações para procura do serviço de saúde mostram a vulnerabilidade física e social da etnia Terena. A efetividade da medida de isolamento social nas aldeias depende do diálogo com lideranças indígenas, engajamento dos profissionais e ações intersetoriais. Descritores: Saúde de Populações Indígenas; Sistema Único de Saúde; Antropologia Cultural; Populações Vulneráveis; Pandemias.

\section{RESUMEN}

Objetivo: Discutir los aspectos fundamentales en el establecimiento de medidas preventivas para abordar el covid-19 entre los pueblos indígenas ante las motivaciones para buscar servicios de salud en los pueblos de la Terra Indígena Buriti, Mato Grosso do Sul, Brasil. Métodos: Estudio teórico-reflexivo basado en supuestos del Sistema Único de Salud y en una investigación etnográfica previa. Resultados: Los pueblos indígenas buscan unidades de salud para recibir asistencia en programas de salud, tratamiento de casos que no pueden resolver y charlar. Tales motivaciones fueron la base para discutir el proceso de indigenización en el enfrentamiento de la pandemia de coronavirus en tierras indígenas. Consideraciones finales: Las motivaciones para buscar el servicio de salud evidencian la vulnerabilidad física y social de la etnia Terena. La efectividad de la medida de aislamiento social depende del diálogo con líderes indígenas, compromiso profesional y acciones intersectoriales. Descriptores: Salud de Poblaciones Indígenas; Sistema Único de Salud; Antropología Cultural Poblaciones Vulnerables; Pandemias. 


\section{INTRODUCTION}

Indigenous peoples represent 5\% of the world's population and one third of the 900 million people living in extreme poverty on the planet ${ }^{(1)}$. In the Americas, on a daily basis, native minorities experience situations of exclusion, marginality and discrimination that put them in greater social and health vulnerability ${ }^{(1-4)}$.

The covid-19 pandemic unveils and reaffirms the scenario of inequalities experienced by population groups worldwide and in Brazil. In the United States of America, there is a greater number of cases of the disease in population groups of Afro-descendant ethnicity, homeless people and of low income. In Australia, there is fear for the catastrophe resulting from the impact of the disease on indigenous people $\mathrm{e}^{(3)}$. In Brazil, these situations happen in a similar way.

Indigenous mortality was four times higher than mortality of the general Brazilian population during the $\mathrm{H} 1 \mathrm{~N} 1$ pandemic in $2019^{(2)}$. Studies describe a high rate of attack in outbreaks of respiratory diseases among indigenous people $\mathrm{e}^{(4-6)}$. This scenario shows the greater susceptibility of this population group to the attack of respiratory diseases, such as covid-19(2). Historically, Brazilian indigenous people have experienced different inequalities related to access to health services due to ethnic-racial disparities and the vulnerability of rural populations ${ }^{(2)}$. This situation corroborates the need for effective public policies aimed at this portion of the population $^{(1-3)}$, especially in the current scenario of coping with the new coronavirus pandemic.

In Brazil, there are reports of efforts by the Ministry of Health to tackle the covid-19 pandemic in indigenous lands. However, the configuration of public health services linked to the National Health System (Brazilian SUS) in the villages and the traditional local healing practices reflect different interests and motivations that influence the resolution of health actions.

Motivation is the "persistent tendency, a chronic inclination to perform certain types of acts and experience certain kinds of feelings in certain situations"(7), such as taking care of health and when to seek or not the health service, critical aspects in prevention and control policies of covid-19. Knowing the motivations to seek health services allows the identification of individualized health care strategies for the indigenous population that have effective results in health promotion, disease prevention, early diagnosis, treatment and rehabilitation.

With this reflection, we aimed to answer the following question: how do motivations that lead indigenous people to seek the Brazilian SUS care in the village can influence the coping with the new coronavirus (covid-19) pandemic in an indigenous village in Mato Grosso do Sul, Brazil? To answer this question and expand knowledge about the performance of the Brazilian State in the health care of indigenous people, we present this theoreticalreflective study based on a previous study ${ }^{(8)}$.

\section{OBJECTIVE}

To discuss the fundamental aspects for establishing preventive measures in the fight against covid-19 among indigenous people in view of the motivations for seeking health services in the villages of Terra Indígena ( $\mathrm{TI}$ ) Buriti (indigenous territory henceforth called TI Buriti), Mato Grosso do Sul, Brazil.

\section{HEALTH CARE OF INDIGENOUS PEOPLE AND METHODO- LOGICAL NOTES}

In Brazil, the SUS guides the health care to indigenous people through the National Policy on Health Care for Indigenous People*, a subsystem organized from Special Indigenous Health Districts in geographic areas divided according to demographic, territorial and ethnic characteristics*.

In each Health District, care is provided by family health teams that work in Basic Health Centers and Central Units. The Health Centers are located in the villages. Primary health care (PHC) is planned and coordinated in two types of Central Units: Type I, located in the villages and Type II, in an urban area, as is the Central Unit of the TI Buriti*. The multidisciplinary indigenous health team that works in PHC is composed of nurses, doctors, indigenous health agents and nursing technicians. The dentist and oral health technician/assistant can be included*. There are also Indigenous Health Houses*, spaces offering support and user embracement for indigenous people referred to medium and high complexity services in the SUS network and their companions ${ }^{(8)}$. The organization of work and flow in the District is performed by the Indigenous Health Care Division (Portuguese acronym: DIASI)*.

Health care in the villages can have the shape of different healing practices, in which forms of care with the traditional knowledge of native people coexist with evidence-based technical knowledge reproduced by health professionals ${ }^{(1)}$. The National Policy on Health Care for Indigenous People establishes the respect and appreciation of traditional indigenous medicine to overcome barriers to access health services, and is a strategy to resolve frequent problems among indigenous people ${ }^{(8)}$. However, there are few studies exploring the organization of health services in villages from the perspective of the actors involved - users and health professionals ${ }^{(2,8)}$.

This theoretical-reflective study is based on assumptions of the National Health System and on a previous ethnographic research ${ }^{(8)}$ based on Interpretive Anthropology ${ }^{(7)}$, through which were identified the motivations for seeking health services in nine villages of TI Buriti, Mato Grosso do Sul, Brazil( ${ }^{(8)}$, from participant observation and semi-structured interviews with indigenous people (Terena ethnicity), and native and non-indigenous health workers working in the Type II Central Unit ${ }^{1}$ and the Basic Health Center ${ }^{(8)}$.

Ethnographic research is characterized by a long period of data collection ${ }^{(7)}$. The investigation period in the Buriti villages started in 2013 with an initial approach to enter indigenous lands, and ended in 2017 after the final report was delivered. The year 2014 was the longest immersion period of the researcher in the community. Through immersions in 2015 and 2016, data were updated, reiterated and ratified in the phases of organization

* Legislation on indigenous health in Brazil:

- On the National Policy on Health Care for Indigenous Peoples, check: Brasil, Fundação Nacional de Saúde. Política Nacional de Atenção à Saúde dos Povos Indígenas. 2nd ed. Brasília: Ministry of Health. 2002. 40p.

- On Indigenous Health Houses and Central Units, check: Ordinance 1.801/2015. Ministry of Health, Special Secretariat for Indigenous Health (Nov 9, 2015).

- On primary health care in the villages, check: Brazil, Ministry of Health. Technical Note 17/2018 - Guiding Document of the Organization of Work Processes for Primary Health Care in Special Indigenous Health Districts. Ministry of Health, Special Secretariat for Indigenous Health (2018). 
and analysis and the bond with the indigenous community and the health team were strengthened ${ }^{(8)}$. A previously prepared script applied to the key informants, who were identified after the period of insertion in the field of study, was used to conduct the semi-structured interviews. The theoretical framework of the study and the information about the social phenomenon learned in the field were considered for the development of the script ${ }^{(8)}$.

Data analysis was based on dialectical hermeneutics ${ }^{(8)}$ and performed concurrently with the collection phase. The permanent contact of the researcher with key informants allowed the validation of the study results with the community. This previous ethnographic research was approved under CONEP Opinion number 134.390 and CEP number $170.397^{(8)}$.

\section{TERENA ETHNICITY OF THE TI BURITI AND THE MOTIVA- TIONS FOR SEEKING THE HEALTH SERVICE}

The Terena ethnicity of the TI Buriti are inserted in the surrounding society with a strong integration of goods and services to their way of life in the villages, such as formal education, for example. However, they lack basic sanitation and part of the community uses a rustic septic tank and does not have access to piped water ${ }^{(8)}$.

According to the previous ethnographic study, the main health problems presented by users of the Central Unit are diabetes and systemic arterial hypertension (SAH). Hypertension was the most prevalent and incident pathology in the community, with 148 new registrations in the HIPERDIA Program (Plan for the Reorganization of Care to Systemic Arterial Hypertension and Diabetes Mellitus). Communicable diseases also persist in the community, with more than 30 cases of parasitosis and diarrhea reported in the same period ${ }^{(8)}$. These problems show the vulnerability of the Terena ethnicity from the TI Buriti to infection by the new coronavirus (SARS-CoV-2) and SARS-CoV-2-related acute respiratory syndrome. The motivations for seeking health services reported by residents, indigenous and non-indigenous health professionals in the region are presented as follows.

\section{Assistance of health care programs offered by the service}

The demand for health services by the Terena ethnicity from the TI Buriti is strongly determined by the list of services offered in health units, as indicated in the previous ethnographic study. Exams are performed, as well as nursing, medical and dental consultations. The health programs observed during the ethnography were: National Immunization Program, Rede Cegonha (prenatal and childcare), National Tuberculosis Control Program, HIPERDIA Program (diabetes and systemic arterial hypertension) and Brasil Sorridente - National Oral Health Policy. Service is provided by appointment or spontaneous demand ${ }^{(8)}$. The provision of these programs to the indigenous population occurs as they are goals to be achieved by the health service. The offer of these programs depends on the care policy established more broadly, regardless of individual needs presented by users. For example, according to the previous study, in 2015, the gynecological examination performed by the nurse was the most frequent procedure in the units ${ }^{(8)}$.

\section{Search for care in "cases we cannot solve" and to talk}

Regardless of the scheduled list of services, the Terena ethnicity of the TI Buriti seek the health units to resolve "cases we cannot solve" and to talk ${ }^{(8)}$. The expression "cases we cannot solve" refers to biological problems treated at the health center in the village. The problems described by respondents and observed in the daily routine in the centers are mainly expressed in terms of symptoms such as fever, pain, flu, cough, shortness of breath, viruses, sharp pain (pneumonia). They also include complications of diseases as diabetes and accidents, when they involve trauma such as fractures ${ }^{(8)}$. The Terena ethnicity also seek the unit to talk to professionals and other people who are in the service ${ }^{(8)}$.

\section{PROCESS OF INDIGENIZATION IN THE TACKLE OF THE NEW CORONAVIRUS PANDEMIC IN INDIGENOUS LAND}

The motivation to go to the unit to talk and treat health problems that the Terena are unable to solve reveals the process of indigenization of health services, which includes the "negotiation and renegotiation, cultural resistance and illustration of the formation of an indigenous identity" in the use of public health space ${ }^{(7-8)}$. Consideration of the indigenization process is essential to establish strategies to tackle the pandemic of the new coronavirus in the village of the TI Buriti. This process legitimizes the action of the Brazilian State in the protection of these peoples and is in line with the United Nations' indigenous health agenda that ratifies the importance of strategies for integrating public health services into the traditional local way of life ${ }^{(1)}$. In this process, nursing professionals play a fundamental role given their proximity to health service users. Among these, indigenous nursing professionals stand out.

In the care of indigenous people, the mere provision of services does not guarantee the resolution of the problem. For example, in 2014 , the aim of the administration of immunizations to the Terena ethnicity according to the child's vaccination calendar was to meet the goal of the National Immunization Program ${ }^{(8)}$. However, for more effectiveness, this campaign could have integrated a broader health education program for the comprehensive promotion of children's health. The vaccination against $\mathrm{H} 1 \mathrm{~N} 1$ performed in the population of the Guarani ethnicity in southeastern Brazil, for example, was not sufficient to prevent the strong outbreak of flu syndrome in the region in $2016^{(6)}$. Other measures to prevent this syndrome should have been implemented considering the lifestyle of this population.

In a broad and critical sense, the vulnerability of indigenous people is exposed when the actions proposed by SUS do not consider the perspective of these people in the service management, that is, when public health actions are not dialogical with the target population ${ }^{(3)}$. The management of health actions for the indigenous population needs to be discussed and deliberated with this group and local leaders ${ }^{(2)}$. In this context, health professionals, especially Nursing, play a fundamental role because of their dialogue with users and other professionals of the Multidisciplinary Indigenous Health Team.

In the current pandemic, SUS health services must establish a dialogical relationship with indigenous leaders. The chiefs have 
the necessary authority to make social isolation feasible, ensuring that people do not transit between villages in a region and adjacent urban areas, that there are no visits to the villages and that they do not seek health services just to talk. In this case, particularly in social isolation, it is necessary to consider the particularities of villages and promote care actions aimed at minimizing the already existing problems. If, on the one hand, the aim of isolation is to protect these vulnerable populations from contamination by the new coronavirus, on the other hand, it also distances these groups from practices to obtain the most basic sustenance. It is essential to avoid the first case or zero patient in a village, because after a case, the entire community is considered contact in influenza syndromes ${ }^{(5)}$. The indigenous way of life, family organization, housing construction and type of occupation vary according to the tradition of each ethnicity and the degree of interaction with the surrounding society. In general, indigenous habits and rituals involve collective activities ${ }^{(6)}$. Indigenous people have less protection against certain etiological agents, which results in illness and/or death ${ }^{(5)}$.

A study on the prevalence of pneumonia in indigenous children in Brazil found an association between the disease and the number of residents and physical characteristics of the houses. The number of people in the same environment favors the transmission of respiratory pathologies. The material with which houses are made can cause a lack of air circulation, humidity and mold, factors related to allergies and respiratory infections ${ }^{(4)}$.

The sanitation conditions of villages that maintain contact with the surrounding society are a challenge for the prevention of the coronavirus infection (covid-19). The control of respiratory outbreaks among native people requires good sanitation and access to treated water ${ }^{(9-10)}$. The reality presented in the ethnographic study conducted with the Terena ethnicity of the TI Buriti showed the lack of piped water and bathrooms in the houses (use of rustic septic tanks), and reflects the reality of many indigenous lands in Brazil $^{(4,8)}$. In these villages, social isolation is impaired because of the contact with the surrounding society thus, basic sanitation becomes a requirement for collective health and implies respect for the environmental and cultural limits of each ethnic group.

In this context, the actions linked to SUS should address covid-19 as one of the cases that indigenous people are unable to resolve ${ }^{(8)}$, thereby favoring the natives' positive interpretation of recommendations for disease prevention and control. However, in this respect, social isolation is not enough. Educational actions are necessary for the identification and early monitoring of signs and symptoms. These actions can be performed by indigenous health professionals living in the villages and through personal contact with the use of different digital media currently available in several villages. In an article** by the Amazônia Real journalism agency, anthropologist João Paula Barreto, of the Tukano ethnicity and a member of the Federation of Indigenous Organizations of the Alto Rio Negro-Amazonas, stated that natives understand covid-19 as a non-indigenous disease that requires treatment of the medicine of "white people". He also referred that the disease

* Available at: <https://amazoniareal.com.br/sem-orientacao-da-sesaiindigenas-combatem-por-conta-propria-novo-coronavírus-nos-territorios/> [cited 2020 Apr 14] is part of the group of problems that leads indigenous people to seek the health unit, instead of traditional forms of cure.

Health education actions need to be translated considering the culture of each indigenous people and, in some cases, the local language. Researches on outbreaks in indigenous villages during the H1N1 pandemic in different locations around the world in 2009 reinforce the importance of health education provided massively by health professionals in the villages for disease control $^{(9-10)}$. Studies on outbreaks and prevalence of respiratory syndromes in Brazil reiterate this aspect ${ }^{(4-6)}$.

Primary health care in Brazil relies on the community health agent. In the villages, the indigenous health agent plays a decisive role in health education and the monitoring of families in the community, especially because the care of doctors, nurses and dentists is provided by appointment in many villages, as in the TI Buriti ${ }^{(8)}$. The shortage of nurses in primary health care hinders the organization of preventive measures. Therefore, ensuring the adequate training of indigenous health agents is key. This training should be provided by nurses, considering their role in the planning of actions. In this process, indigenous leaders must be heard so they can act toward favoring the access and enabling better results for health education actions and the monitoring of families. In villages with telephone and/or internet access, indigenous health agents and other community actors can receive telemedicine support and thus, avoid the transit of health professionals from other areas.

Telemedicine can also assist in the management of people with symptoms of infection by the new coronavirus (covid-19) and other health problems in order to maintain social isolation. Public facilities in the villages do not have infrastructure and qualified professionals to provide medium and high complexity care ${ }^{(8)}$. By telephone contact, the specialized health team can monitor remotely and explain the signs and symptoms of the disease.

The treatment of respiratory outbreaks in indigenous people must consider factors that strengthen the rate of attack of the disease, such as nutrition ${ }^{(9-10)}$. Many indigenous people suffer nutritional deficiencies because they live in remote areas, a fact that also makes them susceptible to developing acute respiratory syndromes ${ }^{(5,9-10)}$. With the isolation necessary to combat covid-19, many indigenous population groups may be left without access to the food needed for a minimal nutritional diet. Not all regions have the necessary conditions for survival from land cultivation ${ }^{(8)}$. Thus, facing the pandemic also involves ensuring that families receive government benefits, such as the Bolsa Família in the own villages.

Although many indigenous people suffer from malnutrition and undernutrition ${ }^{(1)}$, population groups also suffer from the prevalence of chronic noncommunicable diseases such as $\mathrm{SAH}$ and diabetes mellitus ${ }^{(8)}$. These are also common comorbidities among individuals with SARS-CoV-2-related Acute Respiratory Syndrome ${ }^{(3)}$ and this aspect needs to be considered in the disease management policy among indigenous peoples. In acute cases requiring emergency medical care, the individual must be removed from the village and sent to the health service in the city ${ }^{(5)}$. In care services provided to indigenous health, in cases of the new coronavirus outside the villages, it is important that customs of the local culture are taken into consideration, such 
as the accompanying family member and burial rituals specific to each ethnic group.

\section{MEASURES TO FIGHT THE COVID-19 PANDEMIC AMONG INDIGENOUS}

Based on motivations of the Terena ethnicity to seek health services in the TI Buriti, and committed with SUS guidelines, we present the fundamental points for establishing measures to tackle the current pandemic among indigenous people:

- Indigenization of actions, that is, integration of indigenous people in the management of actions for health promotion and disease prevention implemented in the villages, from health education and family monitoring to the early identification of symptoms and rehabilitation, so that such actions acquire the identity of the ethnic group.

- Establishment of a dialogical relationship with indigenous leaders and the entire community.

- Understanding the meanings attributed to covid-19 by each indigenous group and their particular way of life in the management of health measures during the pandemic.

- Social isolation of the community planned with strategies for providing food and receiving the benefits in the villages.

- Expressive health education and monitoring of families by local health professionals and community members with support from indigenous leaders.

- Continuing education and training for the health team, especially the indigenous health agent, with use of telemedicine.

- Whenever possible, telemedicine to monitor individuals with health problems in the villages.

- Treatment of people with covid-19 symptoms outside the village with guarantee of respect for the indigenous culture of health care.

\section{Study limitations}

This reflection has limitations because it is based on results focused on a specific indigenous group. Although this is a limitation, the results provide indications about the need to go beyond the list of services offered by the health service that translates into goals to be reached. Despite the limitations, it shows the need to protect a group of indigenous people for the prevention and control of the new coronavirus pandemic (covid-19) with protective actions that embrace the demands of this group through dialogue with the outside group.

\section{Contributions to the field of nursing, health or public policy}

Considering the lack of specific studies on the involvement and management of infection among indigenous people by the new coronavirus (covid-19), the approach presented here for facing the pandemic in indigenous lands provides important information for care management in the current scenario and for the performance of Brazilian nursing. Thus, the contribution of this reflection lies in its elucidative character, having the indigenous perspective on health care and its relationship with SUS in the village as the background.

\section{FINAL CONSIDERATIONS}

The care provided to indigenous people, especially in primary health care, must consider the population needs as production and social reproduction in order to ensure that health services are willing to provide embracement of the community demands and to integrate them in the care management.

From the literature and the findings of a previous ethnographic study focused on the perspective of indigenous people for seeking SUS services in the TI Buriti, we present general measures to tackle the new coronavirus pandemic in the village with involvement of local health professionals by reinforcing the role of the nursing team, intersectoral actions and the community. The process of indigenization of the actions of combat and management of covid-19 is an important aspect aligned with the differentiated health care required by indigenous populations. We recommend the process of indigenization of the confrontation of the pandemic as a fundamental aspect for the implementation of resolute measures of prevention and control of covid-19 in indigenous lands.

\section{FUNDING}

Research financed by the São Paulo Research Foundation -FAPESP. Process number 2012/03773-8.

\section{ACKNOWLEDGEMENTS}

We thank the health team and the Terena community of the Terra Indígena Buriti of Mato Grosso do Sul, for their welcome and cooperation.

\section{REFERENCES}

1. Permanent Forum on Indigenous Issues, United Nations. Report on the Seventeenth Session, 8-12 April, of Economic and Social Council. New York: United Nations; 2018 [cited 2020 Apr 14];suppl23:1-28. Available from: https://www.un.org/development/desa/indigenouspeoples/ wpcontent/uploads/sites/19/2018/06/Report-on-ForumEnglish.pdf

2. Zavaleta C. COVID-19: review Indigenous peoples' data; Nature. 2020;580(9):185. doi: 10.1038/d41586-020-01032-1

3. Ahmed F, Ahmed N, Pissarides C, Stiglitz J. Why inequality could spread COVID-19. Lancet Public Health. 2020;2:1. doi: 10.1016/ S2468-2667(20)30085-2

4. Cardoso AM, Hortab BL, Santos RV, Escobar AL, Welcha JR, Coimbra Jr CEA. Prevalence of pneumonia and associated factors among indigenous children in Brazil: results from the First National Survey of Indigenous People's Health and Nutrition. Int Health. 2015;7:412-419. doi: 10.1093/inthealth/ihv02 
5. Ministério da Saúde (BR). Investigação de Surto de Síndrome Gripal em Populações Indígenas, Altamira-Pará, abril-setembro de 2010. Boletim Epidemiológico Secretaria de Vigilância em Saúde - Ministério da Saúde - Brasil. [Internet]. 2012 [cited 2020 Apr 14];43(3):11-16. Available from: https://www.saude.gov.br/images/pdf/2014/julho/23/BE-2012-43--3--pag-11-a-16-Sindrome-gripal.pdf

6. Cardoso AM, Resende PC, Paixao ES, Tavares FG, Farias YN, Barreto CTG, et al. Investigation of an outbreak of acute respiratory disease in an indigenous village in Brazil: contribution of influenza $\mathrm{A}(\mathrm{H} 1 \mathrm{N1})$ pdm09 and human respiratory syncytial viruses. PLoS ONE. 2019;14(7):1-15. doi: 10.1371/journal. pone.0218925

7. Geertz C. A interpretação das culturas. Rio de Janeiro: LTC; 2008.470 p.

8. Ribeiro AA. O cuidado no espaço de intermedicalidade em uma aldeia indígena [Tese]. [Ribeirão Preto]: Universidade de São Paulo; 2015.209 p.

9. Chidgzey PJ, Davis S, Williams $\mathrm{P}$, Reeve $\mathrm{C}$. An outbreak of influenza $\mathrm{A}(\mathrm{H} 1 \mathrm{~N} 1)$ virus in a remote Aboriginal community post-pandemic: implications for pandemic planning and health service policy. Aust NZ J Public Health. 2015;39:15-20. doi: 10.1111/1753-6405.12295

10. Pollock SL, Sagan M, Oakley L, Fontaine J, Poffenroth L. Investigation of a pandemic H1N1 influenza outbreak in a remote First Nations community in northern Manitoba, 2009. Can J Public Health. 2012;103(2):90-3. doi: 10.1007/BF03404209 